\title{
Pathobiology of Human Hepatocellular Carcinoma
}

\author{
Michio Imawari*
}

Ann Cancer Res Ther 1(1): 38-40, 1992 / Received 21 Aug 1992

The incidence of hepatocellular carcinoma has been increasing in Japan, and approximately 24,000 patients died of hepatocellular carcinoma in 1989. The incidence is 2.7 times higher in male than in female. Hepatocellular carcinoma is associated with hepatitis B virus infection in about $30 \%$ of cases, and with hepatitis $\mathrm{C}$ virus infection in the most of the remaining cases.

The incidence of hepatocellular carcinoma is high in Africa and East Asia, and that of hepatitis B virus infection is also high in these areas. Thus hepatitis B virus infection has been implicated in the genesis of hepatocellular carcinoma. Indeed it has been reported that hepatitis B virus genome is integrated in hepatocellular carcinoma tissues highly frequently $y^{1 / 14}$. However integration of hepatitis $B$ virus genome has been also reported to exist in non-cancerous hepatic tissue in patients with hepatitis B virus infection. In addition, the incidence of hepatocellular carcinoma in patients with asymptomatic hepatitis $B$ virus infection is not high. These results lead to the conclusion that hepatitis B virus gene itself was not an oncogene. Although hepatitis B virus gene itself is not oncogenic, the $\mathrm{X}$ gene product has been reported to have transactivator function ${ }^{15}{ }^{16)}$ and may play some roles in hepatocarcinogenesis as a promoter. It has been reported that hepatitis $B$ virus $X$-gene-transgenic mice develop hepatocellular carcinoma in a high frequency without any liver injury ${ }^{17}$ although hepatitis B virus $\mathrm{X}$ gene itself is not considered as an oncogene.

In Japan, the incidence of hepatocellular carcinoma associated with hepatitis $C$ virus infection is higher than that with hepatitis B virus infection. Recent progress has revealed that hepatitis $C$ virus is an RNA virus with a positive-stranded genome comprising approximately 10,000 nucleotides $^{18}$. It has been reported that hepatitis

* The Third Department of Internal Medicine, Faculty of Medicine, University of Tokyo (7-3-1 Hongo, Bunkyo-ku, Tokyo 113, Japan)
C virus genome is not integrated in neither hepatocellular carcinoma tissues nor non-cancerous liver tissues. Hepatocellular carcinoma associated with hepatitis $\mathrm{C}$ virus infection is almost always associated with cirrhosis. These data suggest that chronic liver damage plays an important role in the human hepatocarcinogenesis.

Recently Chisari et al. ${ }^{19)}$ has reported that hepatocellular carcinoma develops in hepatitis B virustransgenic mice. They have clearly shown that integration of hepatitis B virus gene itself does not lead to development of hepatocellular carcinoma but chronic liver damage does. They showed that the deposition of large envelop protein of hepatitis $B$ virus in hepatocytes of hepatitis B virus-transgenic mice lead to chronic liver injury followed by development of hyperplasia of the hepatocytes and eventually of hepatocellular carcinoma. Interestingly the incidence of hepatocellular carcinoma in hepatitis B virus-transgenic mice was higher in male mice than in female mice as observed in human hepatocellular carcinoma.

There have been increasing numbers of reports on the abnormalities of chromosomes ${ }^{20-30)}$, and antioncogenes ${ }^{31}$. ${ }^{35)}$ in hepatocellular carcinoma, and they are implicated in the genesis of hepatocellular carcinoma. Chromosome abnormalities are considered to lead to either activation of oncogenes or loss of the function of antioncogenes. The abnormality of p53 antioncogene was first reported in hepatocellular carcinoma cell lines ${ }^{31,32}$. The p53 abnormality was also observed highly frequently in hepatocellular carcinoma from Africa and China, and it was shown to be due to the point mutation at codon $249^{33.34}$. However, Hosono ${ }^{32)}$ has reported that the 553 abnormality is a rare event in hepatocellular carcinoma. Murakami $^{35)}$ has reported that they could not detect the abnormality of p53 gene in any of 21 early hepatocellular carcinoma in Japan and that they could detect the abnormality in only 8 out of 21 advanced 


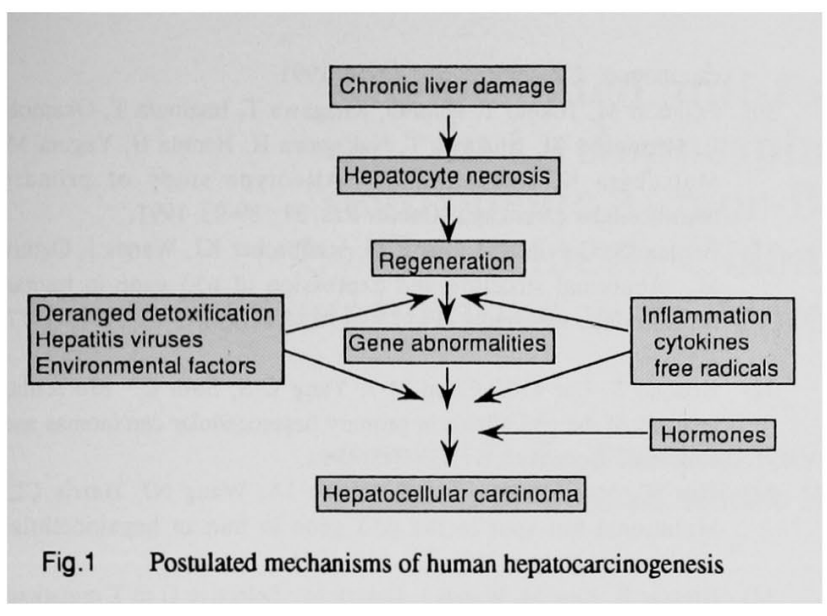

hepatocellular carcinoma in Japan. In addition, point mutation of p53 gene was not restricted to codon 249 , and the abnormalities of RB gene have been reported to be observed in hepatocellular carcinoma with p 53 gene abnormalities. Since codon 249 of p53 gene is the site of point mutation caused by aflatoxin $B_{1}$, the results suggest the implication of aflatoxin in hepatocarcinogenesis in Africa and China.

Androgen receptor has been demonstrated to exist in both hepatocellular carcinoma and non-cancerous liver tissues ${ }^{36}$. When cloned androgen receptor-positive human hepatocellular carcinoma cells were inoculated in male and female nude mice, the incidence of successful implantation of the cells was much higher in male mice than in female mice (unpublished data). The incidence of successful implantation on the cells in female nude mice was increased to that in male mice by supplement with androgenic hormone. Thus androgenic hormone is supposed to affect the growth of hepatocellular carcinoma cells through androgen receptor.

To take the reported results together, we can postulate the mechanisms of hepatocarcinogenesis in human as shown in Fig.1. Chronic liver damage of any etiology leads to liver cell necrosis and regeneration. During liver regeneration, liver cells proliferate and are susceptible to mutagenic agents (environmental factors, hepatitis virus, cytokines and free radicals generated by inflammation, etc.). The growth of transformed hepatocytes may be accelerated by androgenic hormones, hepatitis virus products, and other factors, leading to the genesis of hepatocellular carcinoma.

\section{References}

1) Chakraborty P, Ruiz-Opazo N, Shouval D, Shafritz DA. Identification of integrated hepatitis $B$ virus DNA and expression of viral RNA in an HBsAg producing human hepatocellular carcinoma cell line. Nature, 286: 531-533, 1980.

2) Brechot C, Pourcel C, Louise A, Rain B, Tiollais P. Presence of integrated hepatitis $B$ virus sequences in cellular DNA of human hepatocellular carcinoma. Nature. $286: 533-535,1980$.
3) Edman JC. Gray P, Valenzuela P, Rall LB, Rutter WJ. Integration of hepatitis $B$ virus sequences and their expression in a human hepatoma cell. Nature, $286: 535-538,1980$.

4) Shafritz DA, Shouval D, Sherman $H$, Hadziyannis S, Kew M. Integration of hepatitis $\mathrm{B}$ virus DNA into the genome of liver cells in chronic liver disease and hepatocellular carcinoma-studies in percutaneous liver biopsies and post-mortem tissue specimens. N Engl J Med, 305: 1067-1073, 1981.

5) Simon D, Searls DB, Cao Y, Sun K, Knowles BB. Chromosomal site of hepatitis B virus (HBV) integration in a human hepatocellular carcinoma-derived cell line. Cytogenet Cell Genet, $39: 116-120$, 1985.

6) Imazeki F, Omata M, Yokosuka O, Okuda $K$. Integration of hepatitis $\mathrm{B}$ virus DNA in hepatocellular carcinoma. Cancer, 58 : 1055-1060, 1986.

7) Miyaki M, Sato C, Gotanda T, Matsui T, Mishiro S, Imai M, Mayumi $M$. Integration of region $X$ of hepatitis genome in human primary hepatocellular carcinomas propagated in nude mice. J Gen Virol, $67:$ 1449-1454, 1986.

8) Shaul Y, Garcia PD, Schonberg S, Rutter WJ. Integration of hepatitis $B$ virus DNA in chromosome-specific satellite sequence. J Virol, $59: 731-734,1986$

9) Hino $O$, Shows TB, Rogler CE. Hepatitis B virus integration site in hepatocellular carcinoma at chromosome 17; 18 translocation. Proc Natl Acad Sci USA, 83 : 8338-8342, 1986

10) Wollersheim M, Debelka U, Hofschneider PH. A transactivating function encoded in the hepatitis B virus $X$ gene is conserved in the integrated state. Oncogene, $3: 545-552,1988$.

11) Koike K, Shirakata Y, Yaginuma K, Arai M, Takada S, Nakamura I, Hayashi Y, Kawada M, Kobayashi M. Oncogenic potential of hepatitis B virus. Mol Biol Med, 6: 151-160, 1989.

12) Dejean $A$, De The $H$. Hepatitis $B$ virus as an insertional mutagene in a human hepatocellular carcinoma. Mol Biol Med, 7 : 213-222, 1990.

13) Matsubara $K$, Tokino $T$. Integration of hepatitis $B$ virus DNA and its implications for hepatocarcinogenesis. Mol Biol Med, $7: 243-260$, 1990.

14) Tokino T, Matsubara K. Chromosomal sites for hepatitis B virus integration in human hepatocellular carcinoma. J Virol, $65: 6761$. $6764,1991$.

15) Spandau DF, Lee $\mathrm{CH}$. Trans-activtaion of viral enhancers by the hepatitis B virus $X$ protein. J Virol, 62 : 427-434, 1988.

16) Seto E, Yen TSB, Peterlin BM, Ou J-H. Trans-activation of the human immunodeficiency virus long terminal repeat by the hepatitis B virus X protein. Proc Naul Acad Sci USA, 85 : 8286-8290, 1988.

17) Kim C-M, Koike K, Saito I, Miyamura T, Jay G. HBx gene of hepatitis $B$ virus induces liver cancer in transgenic mice, Nature, 351 : 317-320, 1991.

18) Houghton M, Weiner A, Han J, Kuo G, Choo Q-L. Molecular biology of the hepatitis $\mathrm{C}$ viruses : implications for diagnosis, development and control of viral disease. Hepatology, 14 : 381-388, 1991.

19) Chisari FV, Klopchin K, Moriyama T, Pasquinelli C, Dunsford HA Sell S, Pinkert CA, Brinster RL, Palmiter RD. Molecular pathogenesis of hepatocellular carcinoma in hepatitis B virus transgenic mice. Cell, $59: 1145-1156,1989$.

20) Rogler CE, Sherman M, Su CY, Shafritz DA, Summers J, Shows TB, Henderson A, Kew M. Deletion of chromosome $11 \mathrm{p}$ associated with a hepatitis $B$ integration site in hepatocellular carcinoma Science, $230: 319-322,1985$.

21) Wuu K-D, Kang L, Y-MS, Wang-Wuu S, Hu C-P, Chang C. Karyotipic characterization of an established human hepatoma cell line HA22T/VGH. Cancer Genet Cytogenet, $26: 279-286,1987$.

22) Henderson AS, Ripley $S$, Hino $O$, Rogler CE. Identification of a chromosomal aberration associated with a hepatitis B DNA integration site in human cells. Cancer Genet Cytogenet, $30: 269$. $275,1988$. 
23) Wang HP, Rogler CE. Deletion in human chromosome arms 11p and $13 q$ in primary hepatocellular carcinomas. Cytogenet Cell Genet, 48 : 72-78, 1988.

24) Buetow KH, Murray JC, Israel JL, London WT, Smith M, Kew M, Blanquet V, Brechot C, Redeker A, Govindarajah S. Loss of heterozygosity suggests tumor suppressor gene responsible for primary hepatocellular carcinoma. Proc Natl Acad Sci USA, 86 : 8852-8856, 1989.

25) Zhang W, Hirohashi S, Tsuda H, Shimosato $Y$, Yokota J, Terada M, Sugimura T. Frequent loss of heterozygosity on chromosome 16 and 4 in human hepatocellular carcinoma. Jpn J Cancer Res, 81 : 108$111,1990$.

26) Simon D, Munoz SJ, Maddrey WC, Knowles BB. Chromosomal rearrangement in a primary hepatocellular carcinoma. Cancer Genet Cytogenet, $45: 255-260,1990$.

27) Tsuda $H$, Zhang $W$, Shimosato $Y$, Yokota J, Terada $M$, Sugimura $T$, Miyamura T, Hirohashi S. Allele loss on chromosome 16 associated with progression of human hepatocellular carcinoma. Proc Natl Acad Sci USA, $87: 6791-6794,1990$.

28) Simon D, Knowles BB, Weith A. Abnormalities of chromosome 1 and loss of heterozygosity on $1 p$ in primary hepatomas. Oncogene, 6 : 765-770, 1991.

29) Slagle BL, Zhou Y-Z, Butel JS. Hepatitis B virus integration event in human chromosome $17 \mathrm{p}$ near the $\mathrm{p} 53$ gene identifies the region of the chromosome commonly deleted in virus-positive hepatocellular carcinomas. Cancer Res, $51: 49-54,1991$.

30) Fujimori $M$, Tokino $T$, Hino $O$, Kitagawa $T$, Imamura $T$, Okamoto E, Mitsunobu M, Ishikawa T, Nakagawa H, Harada H, Yagura M. Matsubara K, Nakamura Y. Alleotype study of primary hepatocellular carcinoma. Cancer Res, $51: 89-93,1991$.

31) Bressac B, Galvin KM, Liang TJ, Isselbacher $\mathrm{KJ}$, Wands J, Ozturk M. Abnormal structure and expression of p53 gene in human hepatocellular carcinoma. Proc Nall Acad Sci USA. 87 : 1973-1977. 1990.

32) Hosono S, Lee C-S, Chou M-J, Yang C-S, Shih C. Molecular analysis of the $p 53$ alleles in primary hepatocellular carcinomas and cell lines. Oncogene, $6: 237-243,1991$.

33) Hsu IC, Metcalf RA. Sun T, Welsh JA, Wang NJ, Harris CC. Mutational hot spot in the $\mathrm{p} 53$ gene in human hepatocellular carcinomas. Nature, $350: 427-428,1991$.

34) Bressac B, Kew M, Wands J, Ozturk M. Selective G to T mutations of p53 gene in hepatocellular carcinoma from southern Africa. Nature, 350 : 429-431, 1991.

35) Murakami $Y$, Hayashi K, Hirohashi S, Sekiya T. Aberrations of the tumor suppressor p53 and retinoblastoma genes in human hepatocellular carcinomas. Cancer Res, 51 : 5520-5525, 1991.

36) Nakagama $H$, Gunji $T$, Ohnishi $S$, Kaneko $T$, Ishikawa $T$, Makino R, Hayashi K, Shiga J, Takaku F, Imawari M. Expression of androgen receptor mRNA in human hepatocellular carcinomas and hepatocellular cell lines. Hepatology, $14: 99-102,1991$.
Offprint requests to : $M$. Imawari, The Third Department of Internal Medicine, Faculty of Meficine, University of Tokyo, 7-31, Hongo, Bunkyo-ku, Tokyo 113, Japan 